\title{
Tren Topik Pemberitaan PASCA Pemilihan Presiden pada Portal Berita Online
}

\author{
Puspita Ningtias \\ Program StudillmuPerpustakaan, FakultasIlmuBudaya, UniversitasLancangKuning \\ puspitaningtias18@gmail.com \\ Nining Sudiar \\ Program StudiIlmuPerpustakaan, FakultasIlmuBudaya, UniversitasLancangKuning \\ Email : Sudiar.nining@gmail.com \\ Hadira Latiar \\ Program StudillmuPerpustakaan, FakultasIlmuBudaya, UniversitasLancangKuning \\ Email : hadiralatiar6@gmail.com
}

\begin{abstract}
The purpose of this research is to find out, explain, and analyze the trends of the Post Presidential Election news topics on the online news portal Detik.com and Tribunnews.com 2019. This research method uses quantitative descriptive methods. The results of research from 2 online news portals during the post-presidential election, 17 April to 22 May namely the detik.com portal issued the most number of Prabowo-Sandi news as many as 652 news, while the Jokowi-Amin pair 586 news. Tribunnews.com portal issued the most topics on the Jokowi-Amin couple as many as 537, while the Prabowo-Sandi couple had 536 news. Indicators of topic trends are the direction of the portal detik.com Jokowi-Amin news portal with positive news direction 63 or (10.75\%), negative news direction 16 or (2.73\%), and neutral news direction 507 or (86.52\% ). In the Prabowo-Sandi pair who share positive news 67 or (10.28\%), then the direction of negative news 47 or (7.21\%), while the neutral news direction is 538 or (82.52\%). Meanwhile, the online news portal Tribunnews.com released the news of the Jokowi-Amin pair in the direction of positive news 54 or (10.06\%), negative news direction 27 or (5.03\%), and neutral news direction 537 or (84.92\%). Tribunnews.com released the Prabowo-Sandi pair with 57 or (10.6\%) positive direction, 45 or (8.40\%) negative direction, while the neutral news direction was 434 or (80.97\%).
\end{abstract}

Keywords: Mass media, News, Topic Trends, Presidential

\section{A. PENDAHULUAN}

Setiap manusia membutuhkan sebuah informasi, sehingga menjadikan informasi hal yang sangat penting dalam kehidupan sehari-hari. Informasi berarti sekumpulan data atau fakta yang telah diproses dan dikelola sedemikian rupa sehingga menjadi sesuatu yang mudah dimengerti dan bermanfaat bagi penerimanya (Sri Ati, 2014). Pemberitahuan atau kabar dan berita tentang sesuatu. Sehingga dengan 
kehadiran infomasi, manusia akan mendapatkan pengetahuan tentang dirinya dan keadaan dilingkungan sekitarnya.

Di era globalisasi sebuah informasi sangat mudah didapatkan melalui berbagai media informasi, adapun media informasi terbagi menjadi dua yaitu media cetak dan non cetak, seperti media massa yang mampu memenuhi berbagai kebutuhan informasi bisa disebut media online, suatu media yang dapat diakses dimana saja kapan saja dengan adanya bantuan jaringan internet, salah satunya yaitu portal berita online yang sering disebut website. Portal berita menyugukan nilai dengan informasi yang lebih cepat dibanding layanan konvensional yang masih berupa kertas, serta berisi informasi-informasi yang sedang menjadi tren topik.

Tren topik yaitu sebuah bentuk informasi atau fenomena yang paling populer banyak dicari dan dibicarakan pada waktu tertentu ditengah-tengah masyarakat yang kemudian banyak mendapat tanggapan. Media informasi seperti portal berita online juga akan selalu menampilkan trending topik, guna memberikan informasi kepada pengguna dan pembacanya untuk melihat apa yang orang bicarakan pada masa dan priode tertentu. Salah satu bentuk trending topik yang akan dibahas oleh peneliti yaitu tentang pemilihan presiden dan wakil presiden yang hanya diadakan selama 1 kali dalam 5 tahun, yang bertepatan pada tahun 2019, dengan demikian melihat banyaknya topik yang dibahas mengenai informasi PASCA PILPRES yang terhitung semenjak tanggal 17 April 2019 - 22 Mei 2019 sesaat setelah adanya kegiatan pencoblosan calon presiden dan wakil presiden sampai pengumuman resmi KPU terhadap hasil PILPRES. Membuat berbagai media online terutama portal berita yang saling bersaing dalam membahas program pemberitaan seputar pilpres 2019 untuk mengambil perhatian dari partisipasi masyarakat, dengan begitu portal berita online harus selalu menyajikan berita-berita yang menarik, cepat, aktual dan berimbang terutama berita yang sedang menjadi tren topik untuk memenuhi kebutuhan informasi penggunanya. 
Tren topik ini dilakukan pada dua portal berita online yaitu portal berita Detik.com dan Tribunnews.com merupakan dua diantara sekian banyaknya portal berita online yang memiliki popularitas cukup tinggi di Indonesia berdasarkan banyaknya pengunjung kedua situs tersebut. Versi Alexa.com per 17 April 2019, Detik.com menduduki peringkat kelima di website Indonesia sedangkan Tribunnews.com menduduki peringkat ketiga sebagai situs pemberitan yang banyak dikunjungi di Indonesia(Alexa.com, Alexa.com, 2019). Setiap media memiliki gaya masingmasing dalam penulisan beritanya, mengingat bahwa media bukanlah saluran yang bebas tetapi telah mengkonstruksi berita sedemikian rupa. Peristiwa yang sama dapat diperlakukan secara berbeda oleh media, ada peristiwa yang diberitakan, ada yang tidak diberitakan, ada aspek yang ditonjolkan, ada aspek yang dihilangkan, dengan adanya tren topik pasca pilpres ini nantinya bisa dipakai untuk melihat bagaimana sebuah portal berita online memberikan informasi pasca pilpres tersebut. McQuail mengungkapkan bahwa salah satu cara untuk melihat profesionalitas media adalah dengan mengukur objektivitas media. Pengukuran objektivitas media ini akan dapat mencerminkan aktualisasi nilai dan presentasi media (McQuail, 1992). Objektivitas yaitu mengacu pada bagaimana portal berita online ini mampu memisahkan antara opini dan fakta, serta bagaimana sebuah portal berita online mampu ada pada posisi netral sehingga nantinya berita yang sedang menjadi tren topik menjadi sumber informasi terpercaya bagi masyarakat.

Berdasarkan hal tersebut maka perlu dilakukannya sebuah penelitian di portal Detik.com dan Tribunnews.com ini tentang bagaimana pembahasan tren topik pemberitaan pada pasca pilpres tahun 2019, dengan mengamati informasi yang ada pada portal berita online tersebut yang memuat informasi selama pasca PILPRES dan seperti apa informasi yang selalu disajikan kepada masyarakat, maka penulis tertarik untuk melakukan penelitian yang berjudul "Tren Topik 
Pemberitaan Pasca Pemilihan Presiden Pada Portal Berita Online".

\section{B. METODE}

Penelitaninimenggunakanmetodepeneliti andeskriptifdengan

pendekatankuantitatif, penelitian deskriptif adalah penelitian yang dilakukan untuk mengetahui nilai variabel mandiri, baik satu variabel atau lebih (independen) tanpa membuat perbandingan atau menghubungkan antara variabel satu dengan yang lain (Sugiyono, 2014). Metode ini menggambarkan bagaimana keadaan dilapangan secara sistematis dengan fakta-fakta data yang saling berhubungan, dengan mencari sebuah kebenaran yaitu observasi, dengan begitu peneliti melakukan penelitian berdasarkan pertimbangan bahwa data-data yang dikumpulkan tentang tren topik informasi pemberitaan pasca pilpres di portal berita online yaitu detik.com dan tribunnews.com dan penelitian kuantitatif dilakukan dengan menghitung persentase dari setiap postingan tren topik pasca pilpres pada portal berita online sesuai dengan variable dan indikator penelitian. Hasil dari penelitian ini bersifat deskriptif, yaitu untuk mengambarkan dan meringkaskan berbagai kondisi variable yang timbul pada media massa yang menjadi objek penelitian pemberitaan politik pasca pilpres 2019 pada portal berita online Detik.com dan Tribunnews.com.

Dalam pengumpulan data untuk kepentingan penelitian ini, peneliti menggunakan berbagai macam metode pengumpulan data. Berikut metode yang digunakan. Studi Dokumentasi, Pada teknik ini peneliti memperoleh informasi dari bermacam-macam sumber tertulis dan dokumen yang ada di tempat penelitian (Arikunto, Prosedur Penelitian : Suatu Pendekatan Praktik, 2014). Dokumentasi pada penelitian ini adalah menganalisa portal berita online detik.com dan tribunnews.com. Studi Pustaka, Menurut Nanang Martono (2014:46), stufi pustaka merupakan sebuah proses, mencari, membaca, memahami, dan menganalisis berbagai literatur, hasil kajian (hasil penelitian) atau studi yang berhubungan dengan 
penelitian yanga kan dilakukan. Penelusuran Data Online, Penelusuran data online dilakukan dalam penelitian dengan menganalisa berita mengenai tren topik informasi pasca pilpres pada situs portal berita online detik.com dantribunnews.comdengan cara mencari kata kunci pada indeks portal berita melalui penelusuran tanggal yang dituju lalu pilih sub PILPRES 2019 pada masingmasing portal berita online.

Penelitian ini dilakukan di Fakultas Ilmu Budaya Universitas Lancang Kuning, jalan Yos Sudarso Km. 8 Rumbai, Pekanbaru - Riau, dengan mengamati tren topik pemberitaan pada portal berita online Tribunnews.com., Detik.com dan penelitian dilakukan pada bulan April 2019 - Mei 2019. Objek penelitian yang akan diteliti adalah Tren Topik Informasi Pemberitaan pasca pilpres 2019 dengan mengamati penyebaran informasi melalui portal berita online yaitu Portal Detik.com dan Tribunnews.com.

Subjek dalam penelitian ini yaitu portal berita online Detik.com dan Tribunnews.coom yang mengeluarkan berita tentang tren topik pemberitaan pasca PILPRES.Populasi merupakan suatu Objek atau subjek yang memiliki kualitas dan karakteristik tertentu(Sugiyono, 2014).Populasi adalah keseluruhan subjek penelitian (Arikunto, Prosedur Penelitian : Suatu Pendekatan Praktik, 2014). Populasi dalam penelitian Ini adalah seluruh berita tentang tren topik informasi pasca PILPRES mulai dari 17 April - 22 Mei 2019 yang dikeluarkan pada portal berita online detik.com dantribunnews.com.Sampel adalah bagian dari jumlah dan karakteristik yang dimiliki oleh populasi tersebut (Sugiyono 2014: 120). Berdasarkan pendapat tersebut sampel pada penelitian ini adalah portal berita online detik.com dantribunnews.comyang mengeluarkan berita tentang tren topik informasi pasca PILPRES 2019.

\section{HASIL DAN PEMBAHASAN \\ a. Profil Detik.com}

Detik.com adalah potal web tentang berita, artikel daring dan juga merupakan situs berita populer di 
Indonesia. Sejak 3 Agustus 2011 detik.com menjadi bagian dari PT Trans Corporation, merupakan anak perusahaan CT Corp Server detik.com yang sebenarnya siao diakses pada 30 Mei 1998, namun mulai daring dengan sajian yang lengkap pada 9 Juli 1998. Akhirnya menjadi tanggal lahir dari portal detik.com yang didirikan Budiono Darsono (eks wartawan detik), Yayan Sopyan (eks wartawan detik), Abdul Rahman (mantan wartawan Tempo), dan Didi Nugrahadi. Peliputan utaman detik.com terfokus pada berita politik, ekonomi dan teknologi informasi, setelah situasi politik mulai reda dan ekonomi ulai membaik, detik.com akan melampirkan berita hiburan dan olahraga.

Tanggal 3 Agustus 2011 CT Crop mengakuisisi detik.com (PT Agranet Multicitra Seberkom/ Agrakom). Mulai saat itu detik.com berada di bawah Trans Corp. Chairul Tanjung yaitu pemilik CT Corp membeli detik.com secara total 100\% dengan nulai US\$60 juta atau Rp. 521-540 miliar. Setelah diambil alih, selanjutnya jajaran direktur akan diisi oleh pihak dari Trans Crop sebagai perpanjang tangan CT Crop diranah media dan komisaris utama dijabat jendral (Purn) Bintaro, mantam kapolri, yang saat ini juga menjabat sebagai komisaris utama Carrefour Indonesia yang juga dimiliki Chairul Tanjung.

Sebelum di akuisisi oleh CT corp, saham detik.com dimiliki oleh Agranet Tiger Investement dan Mitsui \& Co. Agranet memiliki 59\% saham di detik.com, dan sisanya dimiliki oleh Tiger 39\% dan Mitsui 2\%.(Detik.com, 2020).

\section{Gambar 1. Logo Detik.Com}

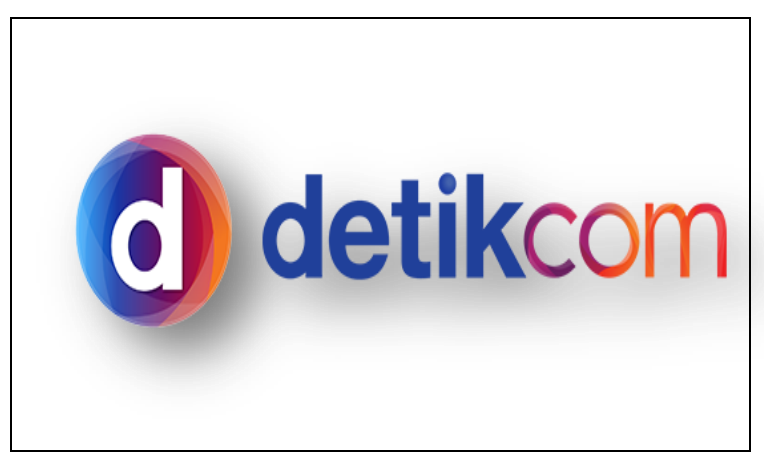

(Sumber :

https://id.wikipedia.org/wiki/Berkas:

Logodetikcom.png)

Gambar 2. Portal Detik.Com 


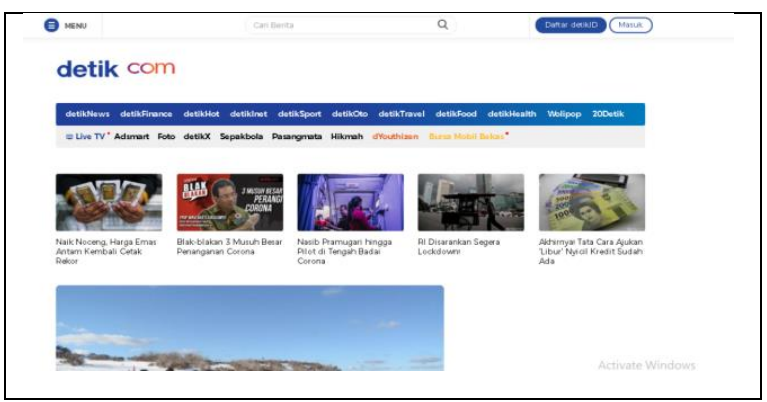

(Sumber : https://www.detik.com/)

\section{b. Profil Tribunnews.com}

Portal berita Tribunnews.com dikelola PT Tribun Digital Online, divisi koran daerah kompas gramedia (Group of Regional Newspaper). Berkantor di pusat Jakarta,situs berita ini menyajikan beritaberita nasional, regional, internasional, olahraga, ekonomi dan bisnis, serta seleb dan lifestyle.

Tribunnews.com juga mengelola forum diskusi, dan komunitas online melalui facebook, dan twitter, serta Google+, selain didukung reporter yang sedang bertugas di Jakarta. Lalu Tribunnews.com tidak hanya jaringan 28 koran daerah atau Tribun Network, tapi juga didukung 500 wartawan dari 22 kota penting di Indonesia.

Selain itu, ada berbagai rubrik lainnya diantaranya Tribuners, Citizen Reporter. Dengan dua rubrik terakhir masyarakat diharapkan ikut berpartisipasi, berbagi informasi dan menyampaikan gagasan dengan ide-ide segar dan pengalaman empiris, terutama untuk mencerdaskan kehidupan bangsa.

Tribunnews.con juga menyajikan berupa halaman digital paper dari koran-koran Tribun Network. Berbeda dari epaper yang merupakan replika dari edisi cetak, digital paper merupakan yang hanya terbit secara online dalam format digital.(Tribunnews.com, 2020).

Gambar 3. Logo Tribunnews.com

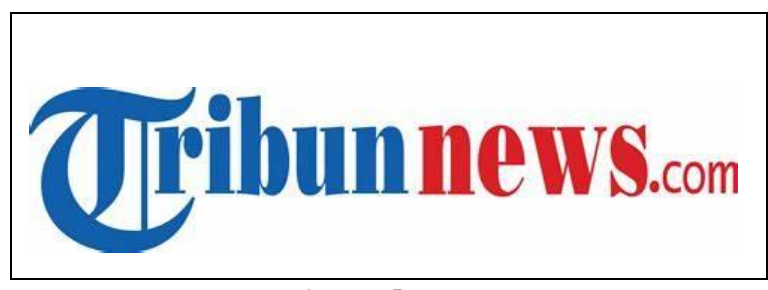

(Sumber :

https://www.tribunnews.com//)

Gambar 4. Portal Tribunnews.com 


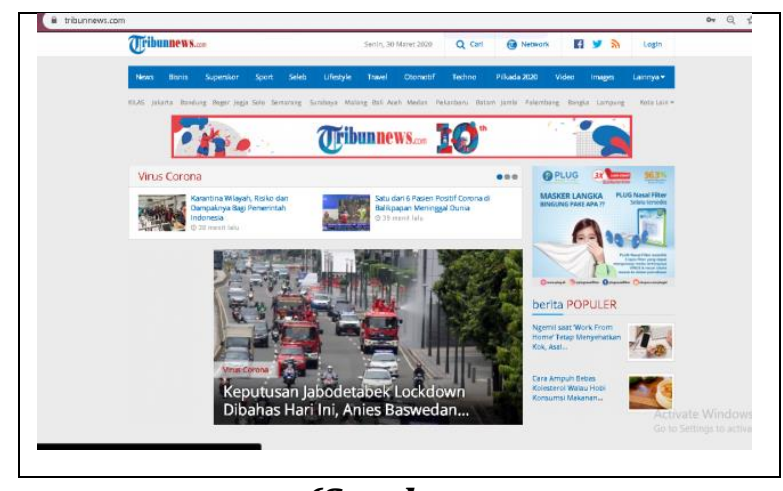

(Sumber :

\section{https://www.tribunnews.com/)}

Adapun hasil dan pembahasan dari penelitian dengan judul Tren Topik Pemberitaan Pasca Pemilihan Presiden Pada Portal Berita Online, peneliti mencari data pada portal berita online yaitu detik.com dan tribunnews.com dengan mencari berita yang membicarakan tentang pilpres 2019 pada tanggal 17 April - 22 Mei dari pencoblosan sampai pengumuman menetapan KPU tentang kemenangan salah satu pasangan pilpres, dengan begitu akan bisa dilihat dari seberapa banyak suatu media mengeluarkan pemberitan mengenai pilpres 2019. Portal media online tidaksertamertajugadapatmelakukan hal yang sama, karena portal berita tetap terikat dengan aturan-aturan jurnalisme yang berlaku, di antaranya tentang netralitas suatu media dalam mengeluarkan berita-beritanya.

Peneliti akan menjabarkan berapa banyak berita yang dibuat pada masingmasing portal berita online Detik.com dan Tribunnews.com mulai dari tanggal 17 April - 22 Mei 2019 yang akan disajikan oleh peneliti dalam bentuk tabel dan grafik.

Table 1. Pemberitaan PILPRES 17 April - 22 Mei 2019 pada Detik.com

\begin{tabular}{|c|c|c|c|c|}
\hline \multirow[b]{2}{*}{ No } & \multirow{2}{*}{$\begin{array}{l}\text { Pasa } \\
\text { ngan } \\
\text { Calo } \\
\text { n }\end{array}$} & \multirow{2}{*}{$\begin{array}{c}\text { Arah } \\
\text { Berita }\end{array}$} & \multicolumn{2}{|c|}{ Detik.com } \\
\hline & & & $\mathbf{F}$ & $\mathbf{P}$ \\
\hline \multirow{3}{*}{1} & \multirow{3}{*}{$\begin{array}{l}\text { Joko } \\
\text { wi- } \\
\text { Amin }\end{array}$} & Positif & 63 & $10,75 \%$ \\
\hline & & $\begin{array}{c}\text { Negati } \\
\mathrm{f}\end{array}$ & 16 & $2,73 \%$ \\
\hline & & Netral & 507 & $86,52 \%$ \\
\hline \multicolumn{3}{|c|}{ Jumlah } & 586 & $100 \%$ \\
\hline \multirow{3}{*}{2} & \multirow{3}{*}{$\begin{array}{l}\text { Prab } \\
\text { owo- } \\
\text { Sandi }\end{array}$} & Positif & 67 & $10,28 \%$ \\
\hline & & $\begin{array}{l}\text { Negati } \\
\mathrm{f}\end{array}$ & 47 & $7,21 \%$ \\
\hline & & Netral & 538 & $82,52 \%$ \\
\hline \multicolumn{3}{|c|}{ Jumlah } & 652 & $100 \%$ \\
\hline \multicolumn{5}{|c|}{ Sumber : Data diolah April 2020} \\
\hline \multicolumn{5}{|c|}{$\begin{array}{l}\text { Pada tabel diatas bahwa portal detik.com } \\
\text { selama PASCA PILPRES mengeluarkan } \\
\text { sebagian kecil } 10.75 \% \text { dengan frekuensi }\end{array}$} \\
\hline
\end{tabular}


63) berita positif tentang pasangan Jokowi-Amin, $2,73 \%$ dengan frekuensi 16) sebagian kecil berita negatif dan (86,52 dengan frekuensi 507) sebagian besar berita netral, jadi portal berita detik.com mengeluarkan seluruh berita pasangan Jokowi-Amin sebanyak 586 berita. Sedangkan pada pasangan Prabowo-Sandi $\quad(10,28 \% \quad$ dengan frekuensi 67) sebagian kecil berita positif, (7,21 dengan frekuensi 47) sebagian kecil berita negatif dan $(82,52 \%$ dengan frekuensi 538) sebagian besar berita netral, jadi portal berita detik.com mengeluarkan seluruh berita pasangan Prabowo-Sandi berjumlah 652 berita. Pada portal berita detik.com lebih banyak mengeluarkan berita tentang pasangan Prabowo-Sandi daibanding Pasangan Jokowi-Amin.

Table 2. Pemberitaan PILPRES 17 April - 22 Mei 2019 pada Tribunnews.com

\begin{tabular}{|c|c|c|c|c|}
\hline \multirow{2}{*}{ No } & \multirow{2}{*}{$\begin{array}{c}\text { Pasa } \\
\text { ngan } \\
\text { Calo } \\
\mathbf{n}\end{array}$} & \multirow{2}{*}{$\begin{array}{c}\text { Arah } \\
\text { Berita }\end{array}$} & \multicolumn{2}{|c|}{$\begin{array}{c}\text { Tribunnews. } \\
\text { com }\end{array}$} \\
\cline { 3 - 5 } 1 & $\begin{array}{c}\text { Joko } \\
\text { wi- }\end{array}$ & Positif & 54 & $10,06 \%$ \\
\cline { 3 - 5 } & Amin & $\begin{array}{c}\text { Negati } \\
\text { f }\end{array}$ & 27 & $5,03 \%$ \\
\hline
\end{tabular}

\begin{tabular}{|c|c|c|c|c|}
\hline & & Netral & \multirow{2}{*}{$\begin{array}{l}456 \\
537\end{array}$} & \multirow{2}{*}{$\frac{84,92 \%}{100 \%}$} \\
\hline \multicolumn{3}{|c|}{ Jumlah } & & \\
\hline \multirow{3}{*}{2} & \multirow{3}{*}{$\begin{array}{l}\text { Prab } \\
\text { owo- } \\
\text { Sandi }\end{array}$} & Positif & 57 & $10,63 \%$ \\
\hline & & $\underset{f}{\text { Negati }}$ & 45 & $8,40 \%$ \\
\hline & & Netral & 434 & $80,97 \%$ \\
\hline \multicolumn{3}{|c|}{ Jumlah } & 536 & $100 \%$ \\
\hline
\end{tabular}

Sumber : Data diolah April 2020

Tabel diatas menunjukkan portal berita Tribunnews.com berita pasangan JokowiAmin mengeluarkan sebagian kecil berita $(10,06 \%$ dengan frekuensi 54$)$, sebagian kecil lagi kearah berita negatif $(5,03 \%$ dari frekuensi 27), sebagian besar berisi berita netral $(84,92 \%$ dengan frekuensi 456) dengan jumlah keseluruhan 537 berita untuk pasangan Jokowi-Amin. Sementara pada pasangan PrabowoSandi sebagian kecil berita positif $(10,63 \%$ dengan frekuensi 57$)$, sebagian kecil lagi berita negatif $(8,40 \%$ dengan frekuensi 45), sebagian besar arah berita netral $(80,97 \%$ dengan frekuensi 434) dengan jumlah keseluruhan 536 berita untuk pasangan Prabowo-Sandi, jadi portal berita tribunnews.com selama PASCA PILPRES lebih banyak mengeluarkan berita pasangan JokowiAmin dibandingkan pasangan PrabowoSandi. 


\section{Grafik 1. Frekuensi Berita pada Portal Detik.com dan Tribunnews.com} 17 April - 22 Mei 2019

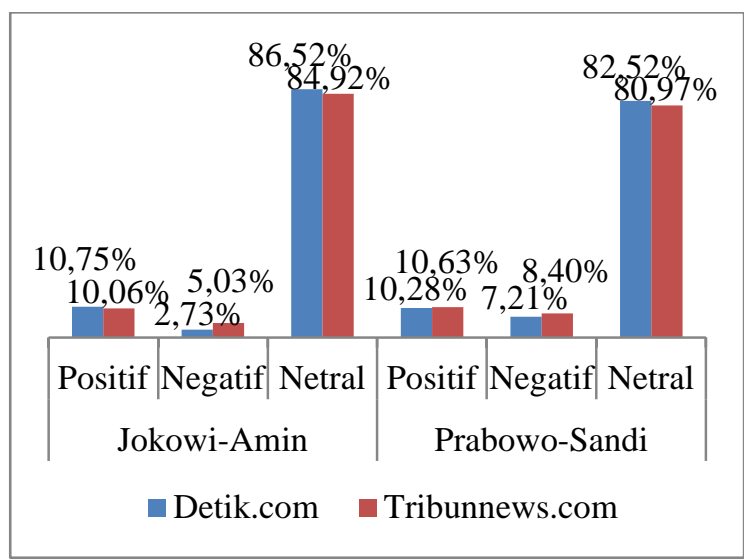

Sumber : Data diolah April 2020

Menurut grafik diatas menunjukkan sebagian kecil arah berita pasangan Jokowi-Amin pada portal berita detik.com $(10,75 \%)$ sementara sebagian kecil lagi pada portal tribunnews.com $(10,06 \%)$. Lalu sebagian kecil arah berita negatif kedua portal tentang pasangan Jokowi-Amin pada portal detik.com $(2,73)$ sementara portal tribunnews.com (5,03\%). Sebagian besar arah berita netral dikeluarkan kedua portal dengan persentase berbeda, portal berita detik.com $\quad(86,52 \%)$ sedangkan tribunnews.com $(84,92 \%)$.

Sementara pada pasangan PrabowoSandi, sebagian kecil arah berita positif diberkan pada kedua portal berita, pada detik.com $\quad(10,28 \%) \quad$ sedangkan tribunnews.com $(10,63 \%)$. Sebagian kecil lagi kearah negatif portal detik.com $(7,21 \%)$, tribunnews.com $(8,40 \%)$. Sebagian besar arah netral kedua portal dengan persentase $(82,52 \%)$ sedangkan portal tribunnews.com $(80,97 \%)$.

Pemberitaan PASCA PILPRES pada kedua portal yaitu Detik.com dan Tribunnews.com mulai dari 17 April-22 Mei, pemberitaan pada bulan April lebih sedikit dibandingkan pada bulan Mei, dikarenakan isu dibulan april hanya mengenai persenan hasil perhitungan sementara real count dan quick count CAPRES dan WAPRES. Sementara, pada bulan Mei kedua portal lebih banyak mengeluarkan berita keberpihakan, perseteruan aksi para pendukung masing-masing pasangan yang mulai memanas, apalagi disaat mendekati hari keputusan KPU atas hasil pemenang pemilihan presiden dan wakilnya.

Portal Detik.com pasangan Jokowi-Amin pada bulan April sebanyak 247 berita dengan pembagian jenis berita yang bersifat pribadi dikeluarkan sebanyak (31 berita) salah satu contoh beritanya 
yaitu "Rileks, Ma'ruf Amin KayuhSepedaStatisJelangNyoblos" ini merupakan contoh berita dari pasangan Jokowi-Amin yang mengarah pada jenis berita pribadi yang tidak seharusnya dimasukkan, dikarenakan tidak ada kaitannya dengan pemberitaan pemilihan presiden dan wakil presiden ditahun 2019, selebihnya sebanyak (216 berita) mengarah pada pemilihan presiden dan wakil presiden seputar hasil sementara dari real count dan quick count. Sedangkan dibulan Mei pemberitaan pasangan Jokowi-Amin lebih banyak dibandingkan bulan April yaitu berjumlah 339 berita, dengan total berita pribadi sebanyak (29 berita) salah satunya "DisinggungEggiSudjana, IniSebenarnya Isi Buku 'Jokowi People Power'”, sebagian lagi sebanyak (307 berita) mengarah pada pemberitan yang khusus membahas tentang PILPRES.

Selanjutnya pada pasangan PrabowoSandi pemberitaan berjumlah 286 berita dengan jenis pemberitaan bersifat pribadi sebanyak 286 berita dengan jenis berita bersifat pribadi sebanyak (29 berita) salah satunya "Awali Kegiatan di
Hari Pencoblosan, Sandiaga Salat Tahajud Berjemaah", lalu selebihnya sebanyak (257 berita) mengarah pada pemberitaan PILPRES. Sementara pada bulan Mei sebanyak 366 berita arah berita bersifat pribadi berjumlah (18 berita) yaitu "BPN JelaskanMaksudRencanaPrabowoTulisSu ratWasiat", lalu sebanyak (384 berita) lainnya mengarah khusu untuk PILPRES. Portal Tribunnews.com pemberitaan untuk pasangan Jokowi-Amin 216 berita, jenis berita pribadi berjumlah (36 berita ) contohnya "Santuni AnakYatim, AliansiRelawanJokowiGelarSyukuranKe menanganJokowi-Ma'ruf Amin”, selebihnya sebanyak (180 berita) mengarah pada pemilihan. Sedangkan pada bulan Mei 321 berita, dikeluarkan berita tentang pribadi (23 berita) salah satunya "BukaBersamaBarengJokowi, ZulkifliHasanMintaTungguHasilPemiluPa da 22 Mei", sementara sebanyak (298 berita) khusu mengenai PILPRES.

Pasangan Prabowo-Sandi berjumlah 232 berita dengan pembagian berita bersifat pribadi sebanyak (39 berita) seperti berikut "Sandiaga: Tiga Hari Ini Banyak 
Berita Lucu-lucu" selebihnya sebanyak (193 berita) tentang PILPRES. Pada bulan Mei dikeluarkan sebanyak 304 berita dengan pembagian berita bersifat pribadi (14 berita) yaitu "Titiek Soeharto Jenguk Pendukung Prabowo yang Diduga Keracunan Makanan Setelah Demo di KPU “ selebihnya berita khusus PILPRES sebanyak (290 berita).

Dapat disimpulkan pada kedua portal tepatnya dibulan April banyak dikeluarkan pemberitaan yang bersifat pribadi dibandingkan pada bulan Mei dikarenakan pada bulan bulan april pemberitaan berfokus pada bagaimana karakter, tindakan dan kegiatan dari masing-masing pasangan, sementara dibulan Mei pemberitaan lebih banyak mengarah khusu pada pemilihan presiden dan wakil presiden apalagi disaat mendekati dengan hari dimana pengumuman hasil dari KPU siapa pemenang dari PILPRES 2019.

\section{SIMPULAN}

Berdasarkan hasil dari penelitian, kedua portal berita online Detik.com dan Tribunnews.com mengeluarkan berita trending topik selama PASCA PILPRES tahun 2019 yang bertepatan pada tanggal 17 April - 22 Mei 2019. Portal berita detik.com mengeluarkan berita pasangan Jokowi-Amin, jumlah frekuensi 586 dengan pembagian arah berita positif 10,75\% (frekuensi 63), arah berita negatif 2,73 (frekuensi 16), arah berita netral 86,52\% (frekuensi 507). Sementara itu detik.com pada pasangan Prabowo-Sandi mengeluarkan berita sebanyak 652, dengan pembagian arah berita positif 10,28\% (frekuensi 67), lalu arah berita negatif 7,21\% (frekuensi 47), sedangkan arah berita netral 82,52\% (frekuensi 538). Sementara itu portal berita online Tribunnews.com mengeluarkan berita pasangan JokowiAmin sebanyak 537 dengan pembagian arah berita positif 10,06\% (frekuensi 54), arah berita negatif 5,03\% (frekuensi 27), dan arah berita netral 84,92\% (frekuensi 537). Sementara itu tribunnews.com mengeluarkan berita pasangan PrabowoSandi sebanyak 536 dengan pembagian arah berita positif 10,6\% (frekuensi 57), arah negatif 8,40\% (frekuensi 45), sedangkan arah berita netral 80,97\% 
(frekuensi 434) untuk pasangan Prabowo-Sandi.

\section{E. SARAN}

Pada portal berita online detik.com dan tribunnews.com telah banyak mengeluarkan berita yang menjadi tren topik PASCA PILPRES 2019. Berdasarkan dengan kesimpulan diatas maka peneliti perlu memberikan saran, antara lain :

a. Sebagai media massa terutama portal berita online seharusnya lebih bersikap profesional agar tidak terpengaruh oleh kepentingan politik. Lebih profesional dalam menyajikan sebuah berita agar dapat digunakan sebagai media penyebaran informasi, kontrol dan sebagai perekat sosial dalam membangun budaya demokrasi yang baik.

b. Portal berita online detik.com dan tribunnews.com sebagai media massa yang berkewajiban memberikan informasi kepada masyarakat, yang seharusnya mampu memberikan informasi yang netral dan tidak memihak salah satu pasangan CAPRES.

c. Masyarakat sebagai konsumen berita agar lebih selektif dalam memilih berita dan menjadikan sebagai rujukan untuk menentukan sebuah suara pada PILPRES.

Bagi peneliti yang akan datang jika mengambil penelitian yang sama maka hendaknya dapat mengembangkan penelitian ini lagi menjadi yang lebih baik.

\section{DAFTAR PUSTAKA}

Agus, I. (2005). Statistic : Komsep dasar dn aplikasinya. Jakarta: Prenada Media.

Alexa.com. (2019, April 17). Alexa.com.

Retrieved September 12, 2019, from Alexa.com:

https://www.similarweb.com/top websites/indonesia/category/new s-and-media 
Alexa.com. (2019, April 17). Alexa.com .

Retrieved September 12, 2019, from Alexa.com :

https://www.similarweb.com/top

websites/indonesia/category/new s-and-media

Arikunto, S. (2014). Prosedur Penelitian :

Suatu Pendekatan Praktik. Jakarta:

Rineka Cipta.

Arikunto, S. (2014). Prosedur Penelitian :

Suatu Pendekatan Praktik. Jakarta:

Rineka Cipta.

Detik.com. (2020, April 17). Detik.com.

Retrieved from Detik.com:

https://www.detik.com/

Emmy, P. (2015). Komparasi Kebenaran,

Relevansi, Keseimbangan Dan

Netralitas Dalam Pemberitaan

(Studi Konten Analisis Terkait

Pemberitaan Pemilu Presiden

2014 di Harian Kompas dan Koran

Sindo): Jurnal studi komunikasi

dan media. Jurnal Studi Komunikasi

dan Media, XIX,

https://media.neliti.com/media/p

ublications/133425-ID- komparasi-kebenaran-relevansikeseimbang.pdf . .

Eriyanto. (2011). Analisis Isi Pengantar Metodologi Untuk Penelitian Ilmu Komunikasi dan Ilmu-Ilmu Sosial Lainnya. Jakarta: Prenada Media Grup.

Hardi, W. (2005). Kajian Koleksi Bidang Linguistik dengan Metode Conspectus di Perpustakaan Fakultas Ilmu Pengetahuan Budaya Universitas Indonesia. repository.ui.ac.id.

Heywood, A., \& Miria, B. (2007). DasarDsar Ilmu Politik. Jakarta: PT Gramedia Pustaka Utama. Ircham, M. (2014). Keberpihakan Media Online terhadap Pasangan Calon Presiden dan Wakil Presiden pada Pemilihan residen Republik Indonesia 2014. Ilmu Komunikasi, http://bppkibandung.id/index.ph p/jpk/article/download/488/264. Irianto, A. (2004). Statistic : Konsep dan aplikasi. Jakarta: Prenada. Juditha, C. (2017). SENTIMEN DAN IMPARSIALITAS ISI BERITA 
TENTANG AHOK DI. Jurnal PIKOM,

57.

Kriyanto, R. (2009). Teknik Praktis Riset

Komunikasi. Jakarta: Erlangga.

Kurniawan, T. (2016). Peran

Perpustakaan Perguruan Tinggi

Dalam Mengembangkan Repositori

Institusi. Pustakaloka, 8(2).

Kusumaningrat, P., \& Kusumaningrat, H.

(2006). Jurnalistik:Teori dan

Praktek. Bandung: Remaja

Rosdakarya.

McQuail. (1992). Teori Komunikasi

Massa.

McQuail. (1992). Teori Komunikasi Massa

: Suatu pengantar. Jakarta:

Erlangga.

McQuail. (1994). Teori Komunikasi

Massa.

McQuail. (1994). Teori Komunikasi Massa

: Suatu pengantar. Jakarta:

Erlangga.

Mokhsen, N. (2019). FGD Sistem

Pengawasan KASN Terhadap

Pelaksanaan Asas Netralitas ASN.

Jakarta.

Mollet, A. (2014, April 16). Five Ways

Libraries Using Instagram to Share
Collections and Draw Public

Interest. Dipetik November 10,

2019, dari

Five\%20ways\%20libraries\%20are

\%20using\%20Instagram\%20to\%2

0share $\% 20$ collections $\% 20$ and $\% 2$

0draw\%20public\%20interest.pdf

Muntashir. (2011). Analisis Webometrics

Pada Perpustakaan Perguruan

Tinggi Negeri di Indonesia.

Fakultas Ilmu Pengetahuan

Budaya, Program Studi Ilmu

Perpustakaan, Universitas

Indonesia.

Pedoman Perpustakaan Perguruan Tinggi. (2004). Jakarta.

Sari, M. P. (2019, November). Fenomena

Penggunaan Media Sosial

Instagram Sebagai Media

Komunikasi Pembelajaran Agama

Islam Oleh Mahasiswa FISIP

Universitas Riau. JOM FISIP, 4(2).

Sri Ati, d. (2014). Dasar-Dasar Informasi.

Jakarta: Universitas Terbuka.

Sugiyono. (2013). Metode Penelitian

Kuantitatif, Kualitatif, dan

Kombinasi (Mixed Method).

Bandung: Alfabeta. 
Sugiyono. (2014). Metode Penelitian

Kuantitatif, Kualitatif, dan

Kombinasi (Mixed Methods).

Bandung: Alfabeta.

Sugiyono. (2014). Metode Penelitian

Kuantitatif, Kualitatif, dan R\&D.

Bandung: Alfabeta.

Supartinah. (2014). Netralitas media massa terhadap pasangan calon gubernur Jawa Tengah 2013 ( Analisis isi berita pasangan calon gubernur Jawa Tengah di Harian Solopos, Suara erdeka, dan Radar Bayumas). Program studi Ilmu Komunikai, Universitas Sebelas Maret, https://digilib.uns.ac.id/dokumen /download/42174/MTQyMTQ1/N etralitas-Media-Massa-TerhadapPasangan-Calon-Gubernur-JawaTengah-2013-Analisis-Isi-BeritaPasangan-Calon-Gubernur-JawaTengah-di-Harian-Solopos-SuaraMerdeka-dan-Radar-BanyumasPeriode-11-April-.

Syahreza, M. F., \& Tanjung , I. S. (2018).

Motif dan Pola Penggunaan Media Sosial Instagram di Kalangan
Mahasiswa Program Studi Pendidikan Ekonomi Unimed. Jurnal Interaksi, 2(1), 61-68. Tribunnews.com. (2020, April 17). Tribunnews.com. Retrieved from Tribunnews.com: https://www.tribunnews.com/ Wardani, A. S. (2019). Jumlah Pengguna Instagram dan Facebook Indonesia Terbesar ke-4 di Dunia. Dipetik Juni 26, 2019, dari (sumber :https://www.liputan6.com/tekno /read/3998624/jumlahpengguna-instagram-danfacebook-indonesia-terbesar-ke-4di-dunia

Webometrics Ranking of World University. (t.thn.). Dipetik Desember 7, 2019, dari Ranking Web of University: https://www.webmetrics.info/en/ asia/indonesia\%20

Yusup, P. M. (2019). Ilmu Informasi, Komunikasi, dan Kepustakaan. Jakarta: Bumi Aksara. 